\title{
An Autoethnographic Report on the Use and Impact of Social Networking Sites as an Approach to Teaching of the Research Process
}

\author{
Almighty C. Tabuena \\ Espiritu Santo Parochial School of Manila Inc., Manila, Philippines \\ 1912 Rizal Avenue cor. Tayuman St., Brgy 344 Zone 35, Santa Cruz, Manila, 1014 \\ Metro Manila, Philippines \\ E-mail: almighty.tabuena@gmail.com
}

\begin{abstract}
Article Info
Abstract

Received November 2021

Accepted November 2021

Published November 2021

Keywords:

approach, impact, research process, social networking sites, teaching

The establishment of the K-12 curriculum has had a significant impact on subject requirements related to the outcome-based education plan and the requisite output for a given research report or requirement. Social networking platforms enable students to effortlessly complete a variety of tasks, such as learning and performance. By intervening in research, social networking sites break down the barriers that limit both students and teachers in the research process. Three methodologies or ideas have arisen, known as approaches, that could help you facilitate teaching research, even if you are not in the research discipline: the Facebook-Personality Network Approach, the Virtual Research Journal, and the Google Immersion Approach. It is considered favorably by some students and users, but there are those who take advantage of its negative aspects. Instead of focusing on the emerging ideas or topics created by coding, I used social networking sites to demonstrate that research can be done anytime, anyplace, for any purpose or cause. According to the outcome-based education paradigm, students found the three techniques highly engaging. In order to be a teacher-researcher, you must utilize your originality and resourcefulness when it comes to all of the resources, devices, and technology, as well as the available social networking sites.
\end{abstract}

C2021 Jurusan Ilmu Pendidikan, FKIP Universitas Lampung 


\section{INTRODUCTION}

In the emergence of the K-12 curriculum, research has been one of the greatest trends in education (Tabuena, 2020), especially in junior and senior high schools, which has been much affected by the implementation, in terms of subject requirements aligned to the outcome-based education scheme and the needed output for a certain research report or requirement. According to this, the loads and other activities that students need to complete, learn, or even perform could be accomplished remarkably easily with the assistance of social networking sites (National Council on Disability, 2011). Through this, the intervention of social networking sites in research breaks down the barrier that limits both students and teachers in the teaching and learning research process.

The primary objective of this short communication study is to identify and describe the approaches in the teaching of the research process using the social networking sites. Teaching research methodology has gotten less attention (Earley, 2014; Wagner et al., 2011). Many universities that teach research methodologies place a premium on information transmission while paying scant attention to the context and application of learned knowledge (Wagner et al., 2011; Gal \& Ginsburg, 1994). This absence of context complicates the process of learning about research for research naive learners. Thus, it is necessary to examine how research methodologies are taught, as equipping students with these research literacy abilities results in greater research output by the individual (Munabi et al., 2006).

\section{METHODS}

\section{Research design}

To extract information on present conditions (Tabuena, Hilario, \& Buenaflor, 2021; Subong, Jr., 2005), the study employed a descriptive research design and an autoethnographic approach to describe and evaluate cultural texts, experiences, beliefs, and practices (Adams et al., 2017). According to Creswell (2009), descriptive research comprises the gathering of data to answer inquiries regarding a subject's present status. 


\section{Data Analysis}

Autoethnography, on the other hand, is a qualitative approach in which the researcher uses self-observation, writing, and reflection to analyze personal and anecdotal experience and connects it to broader cultural, governmental, and societal substances and understandings (Ellis, 2004; Maréchal, 2010).

\section{RESULTS AND DISCUSSION}

Social networking sites, including but not limited to Email, Facebook, YouTube, Messenger, or even Google--the Google Classroom, Google Slides, or Google Documents, are not just for building social interactions, collaborations, or relationships, but for defining social change. In sociology, social change refers to a significant shift or modification in the lifestyle of a society, and students nowadays have diverged from the traditional aspects of education--that's why there is also a need for change in the teaching-learning process in general, especially in research, through these social networking sites.

During the teaching research process, I provided opportunities that were aligned with the underlying trends, issues, and even controversies, not just the social media and/or social networking sites themselves, but rather their content and proceedings, that would ignite their learning interest and curiosity, as well as dispel the common misconception that research is a difficult subject.

\section{Approaches in the Teaching of the Research Process}

Through my new experiences and observations in teaching research as a young individual in the field, there are three methods or principles that have emerged, identified as approaches, that could help you facilitate teaching research, even if you are not in the research discipline. The following are the approaches in the teaching of the research process using the social networking sites: Facebook-Personality Network Approach, Virtual Research Journal, and Google Immersion Approach.

\section{Facebook-Personality Network Approach}

The first approach is what I called the "Facebook-Personality Network Approach", which identifies students' behavior that could affect their individuality, as well as the group's commonness, because the group exerts influence on the development or learning process. For example, one of the trends on Facebook is the use of memes (pronounced as \'mēm $\backslash$ ), a humorous image, 
video, or piece of text, that is copied, often with slight variations, and spread rapidly by Internet users, in which certain topics in research could bring their discourse or discussion to various experiences in life, to generate information among themselves, and to understand the concept you are discussing (Bensaber, 2020).

\section{Virtual Research Journal}

Second, is what I called the "Virtual Research Journal", in which students are allowed to access the internet (in accordance with the school's student handbook) and surf our research page (secret group) named "Practical Research 1 Files", while the discussion and research writing happens--in our case, Practical Research 1 features both qualitative and quantitative research. From the word "virtual", existing or occurring on computers or on the internet, research files and/or journals are provided to them by means of proper uploading guidelines for them to really understand the concept. This approach is highly engaging in two different settings: as a guide reviewer for quarterly assessment, and as a guide method for research writing.

\section{Google Immersion Approach}

Lastly, the third approach could be used beyond the classroom set-up or as a preparation for the next research lesson. I called it the "Google Immersion Approach", (YouTube operates as one of Google's subsidiaries, and others such as Gmail and Google Classroom) in which students are involved by just listening and watching carefully to one content on a specified YouTube Channel or other platforms as a requirement--or in other terms, used as a Flexible Learning Activity (FLA). In this case, I developed instructions and even a YouTube Channel to share with my students. This approach is not just intended to deepen the research understanding of the students, but to be prepared for other shortcomings that might happen, such as the suspension of classes, school activities, homeroom periods, and other related matters.

\section{CONCLUSION}

Social networking sites are viewed positively by those who have studied them and by those who have benefited from them, but there are those who focus on their negative aspects.I used social networking sites in teaching research and as part of my research, not just for the sake of the emerging approaches or 
themes developed in coding, but in the idea that research is a versatile one. It could be done anytime, anywhere, for any specific purpose or reason. In addition, students viewed the three approaches as highly engaging in accordance with the outcome-based education scheme/theory. As a teacherresearcher, you just need to maximize your creativity and resourcefulness for all the materials, devices, the technology, as well as the available social networking sites, and make a plan out of this; plan or design as it involves the intersection of philosophy or theories (Creswell, 2009), strategies of inquiry, and specific methods.

Research education improves consistency in the conduct, interpretation, and response to research findings expressed in recognizable scientific writing styles. According to Aravamudhan and Frantsve (2009), research education and the use of standard formats for scientific writing enhance evidence-based practice by increasing knowledge of, and subsequent acceptance of, new practices. The fast expansion of extremely sophisticated information and the corresponding changes in the working environment make it more necessary to equip students with critical research abilities such as scientific writing in order to stay current (Aravamudhan \& Frantsve, 2009; Johnson et al., 2009). Through the use of the approaches in the research learning process, this initiative in research education assists students in developing and retaining research abilities.

\section{REFERENCES}

Adams, T. E., Ellis, C., \& Jones, S. H. (2017). Autoethnography. The international encyclopedia of communication research methods, 1-11.

Aravamudhan, K., \& Frantsve-Hawley, J. (2009). American dental association's resources to support evidence-based dentistry. The Journal of Evidencebased Dental Practice, 9(3), 139-144.

Bensaber, M. Y. (2020). Humor and Gender: Males and Females' Understanding and Appreciation of Humor in Memes and Written Jokes: A Case Study of 3rd Year Students of English at Frères Mentouri Constantine 1 University (Doctoral dissertation, Ministry of Higher Education).

Creswell, J. W. (2009). Research design: Qualitative and mixed methods approaches. London and Thousand Oaks: Sage Publications.

Earley, M. A. (2014). A synthesis of the literature on research methods education. Teaching in Higher Education, 19(3), 242-253. 
Ellis, C. (2004). The ethnographic I: A methodological novel about autoethnography. Walnut Creek: AltaMira Press.

Gal, I., \& Ginsburg, L. (1994). The role of beliefs and attitudes in learning statistics: Towards an assessment framework. Journal of Statistics Education, 2(2).

Johnson, N. et al. (2009). Research and evidence based practice: Using a blended approach to teaching and learning in undergraduate nurse education. Nurse Education in Practice, 10, 43-47.

Maréchal, G. (2010). Autoethnography. In Albert J. Mills, Gabrielle Durepos \& Elden Wiebe (Eds.), Encyclopedia of case study research (Vol. 2, pp. 43-45). Thousand Oaks, CA: Sage Publications.

Munabi, I. G., Katabira, E. T., \& Konde-Lule, J. (2006). Early undergraduate research experience at Makerere University Faculty of Medicine: A tool for promoting medical research. African Health Sciences, 6(3), 182-186.

National Council on Disability (2011). Technology's impact on employment and opportunities for people with disabilities. The Power of Digital Inclusion. https://ncd.gov/publications/2011/Oct042011

Subong, Jr. P. E. (2005). Statistics for research. Manila: Rex Book Store, Inc.

Tabuena, A. C., Hilario, Y. M. C., \& Buenaflor, M. P. (2021). Overview and exemplar components of the research methodology on the research writing process for senior high school students. International Journal of Trend in Scientific Research and Development, 5(3), 117-126.

Tabuena, A. C. (2020). Students' perception in the implementation of the IMRaD structure approach and its implications on the research writing process. International Journal of Research Studies in Education, 9(7), 55-65.

Wagner, C., Garner, M., \& Kawulich, B. (2011). The state of the art of teaching research methods in the social sciences: Towards a pedagogical culture. Studies in Higher Education, 36(1), 75-88. 